\title{
Multimedia Performances for Pragmatic Tourism
}

\author{
Cane Koteski, Dushko Josheski, Nikola V. Dimitrov, Zlatko Jakovlev, Snezana Bardarova \\ Goce Delcev University of Stip, Stip, Republic of Macedonia \\ Goranco Koteski \\ Army of Republic of Macedonia, Skopje, Republic of Macedonia \\ Aleksandra Zezova \\ Goce Delcev University of Stip, Stip, Republic of Macedonia
}

\begin{abstract}
Audiovisual and digital techniques are becoming the main resources in everyday life, and interdisciplinary transformation of tourism promotion and animation has already been applied in modern tourism. Tourism offers and services should be complete, current, and qualitative through all phases of the planning process, starting from preparation to implementation. The modern tourist offer of services involves production of multivalorized natural, anthropogenic, communicative, and receptive values of a particular facility or geographic area as a tourist destination target. The tourist or client should experience complete "tour-retour", or as stated in the tourism "I came, saw, took, in order to come back again”, through all the stages, from the preparation of the travel, the stay, up to the departure. Tourism, in the near future, or the tourist dialectical development in order to be completely realized, must pass through the so-called tourist triad from audiovisual or real, to virtual or imagined and to virtuous or perfect. In that case, an ecstasy of admiration, enhancement, prowess, joy, pleasure, excitement, success, and happiness will cause tourists to visit the place again. In order to experience the previously mentioned states, arrangement from professionals, tourist managers, and animators from various areas is of great importance.
\end{abstract}

Keywords: multimedia, compilations, tourist, triad, audiovisual, virtual, animations, pragmatic tourism

\section{Introduction}

Contemporary tourism substantially follows and practices all the trends of the multimedia society and appropriately values and manages them (Goeldner \& Ritchie, 2011). By following this, tourism can become perfect and pragmatic. Without the application of different forms of the multimedia performances in the tourist offer, there is not any tourism progress in the global world as a whole, including the Republic of Macedonia (Marinoski, 2006).

Cane Koteski, Ph.D., assistant professor, Faculty of Tourism and Business Logistics, Goce Delcev University of Stip. Email: cane.koteski@ugd.edu.mk.

Dushko Josheski, MSc. teaching assistant, Faculty of Tourism and Business Logistics, Goce Delcev University of Stip.

Nikola V. Dimitrov, Ph.D., associate professor, Faculty of Tourism and Business Logistics, Goce Delcev University of Stip.

Zlatko Jakovlev, Ph.D., associate professor, Faculty of Tourism and Business Logistics, Goce Delcev University of Stip.

Snezana Bardarova, MSc., assistant, Faculty of Tourism and Business Logistics, Goce Delcev University of Stip.

Goranco Koteski, Lieutenent-General, Chief of the General Staff, Army of Republic of Macedonia.

Aleksandra Zezova, Ph.D., assistant professor, Faculty of Tourism and Business Logistics, Goce Delcev University of Stip.

Correspondence concerning this article should be addressed to Dushko Josheski, Faculty of Tourism and Business Logistics, Goce Delcev University of Stip, Gevgelija 1480, Republic of Macedonia. Email: dushkojosheski@gmail.com. 
In the following parts of this paper, we will present our perceptions of the multimedia performances which will contribute to better tourism in the Republic of Macedonia.

\section{Methodology}

The methodology used in this paper includes the following:

(1) Sounding the existing situation of all natural objects, processes, and appearances, of all anthropologic objects, events, and manifestations, of the receptive objects, and communicative infrastructural objects and resources, all included in the tourism function in the Republic of Macedonia;

(2) Citing information from books, brochures, flyers, DVDs, advertisements, maps, and other products linked with tourism;

(3) Personal experiences from perennial observation, tracking, and contribution in different manifestations, events (Marinoski \& Korunovski, 2008).

\section{Techniques for Data Analysis}

The techniques for analyzing the data are as follows:

(1) Organizing the data of different resources and objects and presenting them in tables (see Tables 1-5 below);

(2) Grouping, planning, preparation, and realization of different audiovisual, virtual, and virtuous multimedia performances, in function of the tourism in the Republic of Macedonia (see Table A1 in Appendix A);

(3) Making a comparative preview of some tourist multimedia performances in the Republic of Macedonia (see Figure A1 in Appendix A).

Table 1

Types of Resources and Number of Natural, Anthropogenic, Receptive, and Communicative Objects Related With Tourism in the Republic of Macedonia

\begin{tabular}{|l|l|}
\hline Resource types & Objects (actual situation, approximate number) \\
\hline \multirow{5}{*}{$\begin{array}{l}\text { Natural objects, processes, and } \\
\text { appearances }\end{array}$} & Mountains (40) \\
\cline { 2 - 3 } & Caves (200) \\
\hline & Cliffs (14) \\
\hline & Canyons (4) \\
\hline & Exceptional, discrete, and research reserves (50) \\
\hline & Natural monuments (152) \\
\hline & Volcanoes, plateau, flagstones, stones, land figures, hubs, etc. \\
\hline & Lakes (160 in which 50 are natural and 110 are artificial) \\
\hline & Rivers (10 longer than 50 km) \\
\hline & Popular sources (12) \\
\hline & Waterfalls (10) \\
\hline & Highest waterfall (138 m) \\
\hline & Thermal sources (18) \\
\hline & Baths (8) \\
\hline & Distinct landscapes (25) \\
\hline Climate \\
\hline
\end{tabular}


(Table 1 continued)

\begin{tabular}{|c|c|}
\hline Resource types & Objects (actual situation, approximate number) \\
\hline \multirow{7}{*}{ Anthropogenic objects, manifestations } & Museums (55) \\
\hline & Archeological localities $(4,293)$ \\
\hline & Churches and monasteries (992) \\
\hline & Objects with ottoman architecture (228) \\
\hline & Walls and bridges (47) \\
\hline & Zoos (2) \\
\hline & Festivals, parties, sports, and other manifestations (250) \\
\hline \multirow{6}{*}{ Receptive objects } & Hotels, apartments, and other accommodation objects (486) \\
\hline & Catering facilities $(4,740)$ \\
\hline & Wineries $(80)^{2}$ \\
\hline & Event facilities (30) \\
\hline & Ski resorts (8) \\
\hline & Gyms (20) \\
\hline \multirow{7}{*}{ Communicative infrastructural objects } & Road networks (4.370 km) \\
\hline & Roads (937 km) \\
\hline & Regional roads (3.433 km) \\
\hline & Highway roads $(131 \mathrm{~km})$ \\
\hline & Airports (2) \\
\hline & Railway open lines (699 km) \\
\hline & Electrified main line $(234 \mathrm{~km})$ \\
\hline
\end{tabular}

Note. Sources: Marinoski (2006); Marinoski and Korunovski (2008); Stojmilov (2003; 2005); http://www.stat.gov.mk/.

Table 2

Types of Natural Resources and Multimedia Performances

\begin{tabular}{|c|c|c|c|}
\hline \multicolumn{4}{|c|}{ Natural resources/natural values } \\
\hline \multirow{2}{*}{ Types of resources } & \multicolumn{3}{|c|}{ Multimedia performances } \\
\hline & Audiovisual & Virtual & Virtuous \\
\hline $\begin{array}{l}\text { In relief (75\% mountains, } \\
\text { 92\% hill lands) }\end{array}$ & \multirow{5}{*}{$\begin{array}{l}\text { Visits, excursions, and stays } \\
\text { enriched with signs, flyers, maps, } \\
\text { brochures, books, signalizations, } \\
\text { signboards, telescopes for } \\
\text { panoramic views, info center, etc. }\end{array}$} & \multirow{5}{*}{$\begin{array}{l}\text { Artificial access of the visits, } \\
\text { promenades, and stays enriched } \\
\text { with taking photos, observations, } \\
\text { drawings, shootings, virtual } \\
\text { panoramas, etc. (the Internet, TV, } \\
\text { DVDs, mobile phones, GPRS, } \\
\text { etc.) }\end{array}$} & \multirow{5}{*}{$\begin{array}{l}\text { Shooting clips, movies, DVDs, } \\
\text { videos of rare natural } \\
\text { phenomena, awards for best } \\
\text { photographs, recorded clips, } \\
\text { etc., made by the visitors }\end{array}$} \\
\hline Climate hydrography & & & \\
\hline Biogeographic & & & \\
\hline Minerals & & & \\
\hline Landscapes & & & \\
\hline
\end{tabular}

Table 3

Types of Anthropogenic Resources and Multimedia Performances

\begin{tabular}{|c|c|c|c|}
\hline \multicolumn{4}{|c|}{ Anthropogenic resources/anthropogenic values } \\
\hline \multirow{2}{*}{$\begin{array}{l}\text { Types of anthropogenic } \\
\text { resources }\end{array}$} & \multicolumn{3}{|c|}{ Multimedia performances } \\
\hline & Audiovisual & Virtual & Virtuous \\
\hline Ethno-social & \multirow{4}{*}{$\begin{array}{l}\text { Making a variety of visual and } \\
\text { audio promotional materials } \\
\text { (brochures, flyers, maps, CDs, } \\
\text { DVDs, movies, books, etc.) }\end{array}$} & \multirow{4}{*}{$\begin{array}{l}\text { Virtual tours in several } \\
\text { buildings, rooms, yards, and } \\
\text { their environment. Making more } \\
\text { targeted videos, advertisements, } \\
\text { and movies for massive usage } \\
\text { (the Internet, TV, DVDs, and } \\
\text { mobile phones) }\end{array}$} & \multirow{2}{*}{$\begin{array}{l}\text { Open museum of various } \\
\text { multimedia reconstructions of } \\
\text { scenes from life (work, } \\
\text { historical battles, contests, etc.) }\end{array}$} \\
\hline $\begin{array}{l}\text { Cultural and historical } \\
\text { values }\end{array}$ & & & \\
\hline Manifestation & & & \\
\hline Ambient & & & actors, students, and visitors \\
\hline
\end{tabular}

${ }^{1}$ See website about Macedonian hotels industry (http://macedonian-hotels.mk/mk).

2 Also see the website of the Balkan wine routes (http://www.balkanwineroute.com/mk) and the History of R. Macedonia website (http://www.macedonium.org/). 
Table 4

Types of Receptive Resources and Multimedia Performances

\begin{tabular}{|c|c|c|c|}
\hline \multicolumn{4}{|c|}{ Receptive resources/receptive values } \\
\hline \multirow{2}{*}{ Types of receptive resources } & \multicolumn{3}{|c|}{ Multimedia performances } \\
\hline & Audiovisual & Virtual & Virtuous \\
\hline Hotels & \multirow{5}{*}{$\begin{array}{l}\text { Billboards, panels, signs, } \\
\text { signalizations, } \quad \text { brochures, } \\
\text { flayers, maps, CDs, DVDs, etc. }\end{array}$} & \multirow{5}{*}{$\begin{array}{l}\text { Virtual tours, movies, clips, } \\
\text { digital menus, and } \\
\text { advertisements, for massive } \\
\text { usage (through the Internet, TV, } \\
\text { DVDs, mobile phones, etc.) }\end{array}$} & \multirow{5}{*}{$\begin{array}{l}\text { Animations and animators, } \\
\text { combined multimedia } \\
\text { performances, } \\
\text { entertainments, with active } \\
\text { contribution from the tourists, } \\
\text { etc. }\end{array}$} \\
\hline Restaurants & & & \\
\hline Agencies & & & \\
\hline Surveys & & & \\
\hline Other objects & & & \\
\hline
\end{tabular}

Table 5

Types of Communicative Resources and Multimedia Performances

\begin{tabular}{|c|c|c|c|}
\hline \multicolumn{4}{|c|}{ Communicative resources/communicative values } \\
\hline \multirow{2}{*}{$\begin{array}{l}\text { Types of communicative } \\
\text { resources }\end{array}$} & \multicolumn{3}{|c|}{ Multimedia performances } \\
\hline & Audiovisual & Virtual & Virtuous \\
\hline Roads & \multirow{7}{*}{$\begin{array}{l}\text { Advertising boards, billboards, } \\
\text { signs, signalizations, brochures, } \\
\text { flyers, maps, menus, CDs, } \\
\text { DVDs, etc. }\end{array}$} & \multirow{7}{*}{$\begin{array}{l}\text { Virtual tours, movies, clips, and } \\
\text { digital ads, for massive usage } \\
\text { (through the Internet, TV, } \\
\text { DVDs, mobile phones, etc.) }\end{array}$} & \multirow{7}{*}{$\begin{array}{l}\text { Animations and animators, } \\
\text { combined multimedia } \\
\text { performances, and } \\
\text { entertainments, with active } \\
\text { contribution from the tourists, } \\
\text { etc. }\end{array}$} \\
\hline Lines & & & \\
\hline Airports & & & \\
\hline Ports & & & \\
\hline $\begin{array}{l}\text { Electronic communications } \\
\text { (the Internet, mobile } \\
\text { phones, GPRS, etc.) }\end{array}$ & & & \\
\hline $\begin{array}{l}\text { Other objects (gas stations, } \\
\text { services, etc.) }\end{array}$ & & & \\
\hline $\begin{array}{l}\text { Applications of all types of } \\
\text { vehicles }\end{array}$ & & & \\
\hline
\end{tabular}

\section{Results}

From the presented indicators, it can be seen that the Macedonian tourist resources are not valued enough or used. Scilicet, the focus of the tourist managers is still the offer of tourist arrangements without the elements of art tourism.

The contemporary tourism involves engagements of various art managers or art animators (artists, entertainers, performers, producers, jugglers, etc.), meaning adepts whose professions enrich and update the tourist promotion significantly (Hansome, 2012).

It is a matter of fact that the Republic of Macedonia possesses various natural, anthropogenic, receptive, and communicative resources, values, and objects (Stojmilov, 2003; 2005) ${ }^{3}$. However, a great part of them are not valued and used by the tourist economy and by the tourists in general. Given such circumstances, the tourist promotion is dominated by the offer of the so-called cultural products: postcards, books, brochures, souvenirs, and significantly less order of tourist DVD movies, clips, etc.. In that direction of satisfying the tourist needs and desires, there is a need for production and offer of various multimedia audiovisual products which, in a modern, fast, and simple way, will do the transformation in tourism (Kolb, 2006).

\footnotetext{
${ }^{3}$ Also see illustrated biography entitled Macedonia tourist pearl. Retrieved from http://www.makedonskibiser.com.mk.
} 


\section{Discussion}

There is a need for complete and quality production multivalirized performances for promotion of the natural objects, processes, and appearances, anthropogenic objects and manifestations, receptive objects, and communicational infrastructural objects and resources, as a goal of tourist destination (Swarbrooke, Beard, Leckie, \& Pomfret, 2003).

In order to plan, make, and realize the mentioned, the following are needed:

(1) Application of interdisciplinary audiovisual and digital techniques, transformation of the tourist promotion and animation;

(2) The tourist/guest needs to fill the complete "tour-retour" (going forward/going back) or as it is said in tourism "I came, I saw, I took";

(3) In order to realize the tourism and touristic dialectical development, it must experience an art travel triad: from audiovisual or real, to virtual or imagined and to virtuous or perfect;

(4) The tourists have to experience an "ecstasy" of admiration, prowess, enhancement, delight, enjoyment, excitement, and happiness;

(5) An engagement of professional staff, tourist managers, and animators from various areas (tourist agents, custodians, artists, showmen, jugglers, masquerade, extras, models, etc.) for the realization of the tourist mission;

(6) Preparation, promotion, reproduction, reconstruction, and revitalization of various audiovisual, virtual, and virtuous multimedia animations and presentations which are a consequence of the natural areas and closed areas through media and various digital appliances;

(7) The prime goal of the promotion, animation, and development of masterful/artificially perfect, profitable, quality, practical, and pragmatic tourism;

(8) Tourism which practices valorized travel, recreation, holiday, education, and entertainment based on the principle of sustainability and protection of the natural environment.

\section{Axiom: “Tourism, an Opened Theater With Free Spirit”}

The following are examples of multimedia performances (natural, cultural, etc.):

(1) Reconstruction of caves in which the human lived, artifacts (objects, figures, maquette, etc.), and active figures (performances from real life (participants: students, artists, and others));

(2) Reconstruction of terrestrial and pile dwelling in which the human lived, artifacts (objects, figures, maquette, etc.), and performances from real life (participants: students, artists, and others);

(3) Reconstruction of housings with several cabins in which the human lived, artifacts (objects, figures, maquette, etc.), and performances from real life (participants: students, artists, and others);

(4) Reconstruction of specific places, objects, and activities (temples, watermills, small dairies, sheds, mowing, reaping, weaving, etc.), artifacts (objects, figures, maquette, etc.), and performances from real life (participants: students, artists, and others);

(5) Reconstruction of housings with various longhouses and urban houses in which the human lived, artifacts (objects, figures, maquette, etc.), and performances from real life (participants: students, artists, and others);

(6) Reconstruction of historical housings (battles, contests, fairs, weddings, etc.), active figures, and performances from the event (participants: students, artists, and others);

(7) Reconstruction of other objects, events, cultural performances (entertainment, festival, fair), etc.. 


\section{Conclusion}

Our recap on this broad subject involves the following:

(1) Engagement of professional staff, tourist managers, and animators from various areas (tourist agents, custodians, artists, showmen, models, etc.) for the realization of the tourist mission;

(2) For realization of the multimedia performances, various facilities, instruments, techniques, etc., will be used;

(3) Preparation, promotion, reproduction, reconstruction, and revitalization of various audiovisual, virtual, and virtuous multimedia animations and presentations which are a consequence of the natural areas and closed areas, through media and various digital appliances;

(4) The prime goal of the promotion, animation, and development of masterful/artificially perfect, profitable, quality, practical, and pragmatic tourism;

(5) Tourism which practices valorized travel, recreation, holiday, education, and entertainment based on the principle of sustainability and protection of the natural environment.

\section{References}

Goeldner, R., \& Ritchie, J. R. (2011). Tourism: Principles, practices, philosophies. Hoboken, NJ: John Wiley \& Sons.

Hansome, S. (2012). Hosting a memorable event. Final Project, Central Ostrobothnia University of Applied Sciences, Degree Program in Tourism.

Kolb, M. B. (2006). Tourism marketing for cities and towns. Burlington: Elsevier Science.

Marinoski, N. (2006). Tourist geography. Ohrid.

Marinoski, N., \& Korunovski, S. (2008). Macedonia: Land of tourism. Skopje: INA Commerce.

Stojmilov, A. (2003). Physical geography of the Republic of Macedonia. Skopje: University SS. Cyril and Methodius Library.

Stojmilov, A. (2005). Socio-economic geography of the Republic of Macedonia. Skopje: University SS. Cyril and Methodius Library.

Swarbrooke, J., Beard, C., Leckie, S., \& Pomfret, G. (2003). Adventure tourism: The new frontier. Oxford: Elsevier Science.

\section{Appendix A}

Table A1

Preview of Several Multimedia Performances as a Tourism Function in the Republic of Macedonia

\begin{tabular}{|c|c|c|c|c|}
\hline Locality & \begin{tabular}{|l|l} 
Description of the performance \\
\end{tabular} & Audiovisual & Virtual & Virtuous \\
\hline Krusevo & $\begin{array}{l}\text { During the year, the town is visited by a great number of tourists. The } \\
\text { visitors have the opportunity to visit more objects, to take more } \\
\text { photographs, and to record videos. Various promotional materials, } \\
\text { souvenirs, etc., can be supplied. There is a manifestation "Krushevska } \\
\text { Republika" and "Ethno-city Krushevo" held annually. The visitors do } \\
\text { not have the opportunity to participate directly as models or actors. } \\
\text { There is not any opportunity for a panoramic view with telescope. }\end{array}$ & + & + & - \\
\hline “Galicka Svadba” & $\begin{array}{l}\text { On July 12, Petrovden, the village Galicnik is visited by a great } \\
\text { number of tourists. The visitors have the opportunity to see the } \\
\text { "Galicka Svadba”, to take photographs, and to record videos. } \\
\text { Various promotional materials, souvenirs, etc., can be supplied. The } \\
\text { visitors do not have the opportunity to participate directly as models } \\
\text { or actors: pairs, wedding guests, etc.. }\end{array}$ & + & + & - \\
\hline Kolesino Waterfall & $\begin{array}{l}\text { During the year, the waterfall is visited by a great number of } \\
\text { tourists. The visitors take photographs and record clips from the } \\
\text { waterfall and its surrounding areas. Various promotional materials, } \\
\text { souvenirs, etc., can be supplied. Annually, there is a wedding } \\
\text { registration in front of the waterfall. The visitors do not have the } \\
\text { opportunity to participate directly as actors, etc.. }\end{array}$ & + & \pm & - \\
\hline
\end{tabular}


(Table A1 continued)

\begin{tabular}{|c|c|c|c|c|}
\hline Locality & Description of the performance & Audiovisual & Virtual & Virtuous \\
\hline Bone bay & $\begin{array}{l}\text { During the year, this primeval housing is visited by a great number of } \\
\text { tourists. The visitors have the opportunity to visit the museum and } \\
\text { Roman citadel, to take photographs, and to record videos. There is } \\
\text { not any opportunity for a panoramic view with telescope. During the } \\
\text { cultural manifestation, "Ohrid Summer", the tourists have the } \\
\text { opportunity to follow various events in an open stage. The visitors do } \\
\text { not have the opportunity to follow the real life of the primeval human, } \\
\text { and there is not any active model, animator, entertainer, etc.. The } \\
\text { visitors do not have the opportunity to participate in performances as } \\
\text { models and actors. }\end{array}$ & + & \pm & - \\
\hline Cave Peshna & $\begin{array}{l}\text { During the year, the cave is visited by a great number of tourists. } \\
\text { The visitors take photos and record clips from the cave and its } \\
\text { surrounding areas. A promotional material can rarely be found. The } \\
\text { object is ruined and neglected. Restoration of the castle, } \\
\text { organization of the vital knightly contests, etc., had been planned. }\end{array}$ & \pm & - & - \\
\hline Ohrid's castle & $\begin{array}{l}\text { During the year, the castle is visited by a great number of tourists. } \\
\text { The visitors have the opportunity to take photos and record videos. } \\
\text { They do not have the opportunity for a panoramic view with } \\
\text { telescope. The visitors do not have the opportunity to actively } \\
\text { participate in human life in the castle, and there is not any active } \\
\text { model, animator, actor, entertainer, etc.. The visitors do not have the } \\
\text { opportunity to participate in performances as models, actors, etc.. }\end{array}$ & \pm & - & - \\
\hline Capari’s carnival & $\begin{array}{l}\text { There is a carnival organized in the village Capari, Bitola, on } \\
\text { January } 14 \text {. The carnival is greatly visited, but there is not any } \\
\text { tourist or other promotion for it. Similar activities which can be } \\
\text { valorized are Kolede, Vodici, surrounding churches, monasteries, } \\
\text { and the natural areas: rivers, waterfalls, areas for mountaineering, } \\
\text { landscapes, etc.. }\end{array}$ & 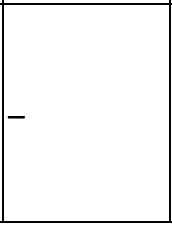 & - & - \\
\hline
\end{tabular}

Notes. +: represented; \pm : insufficiently; and -: not represented.

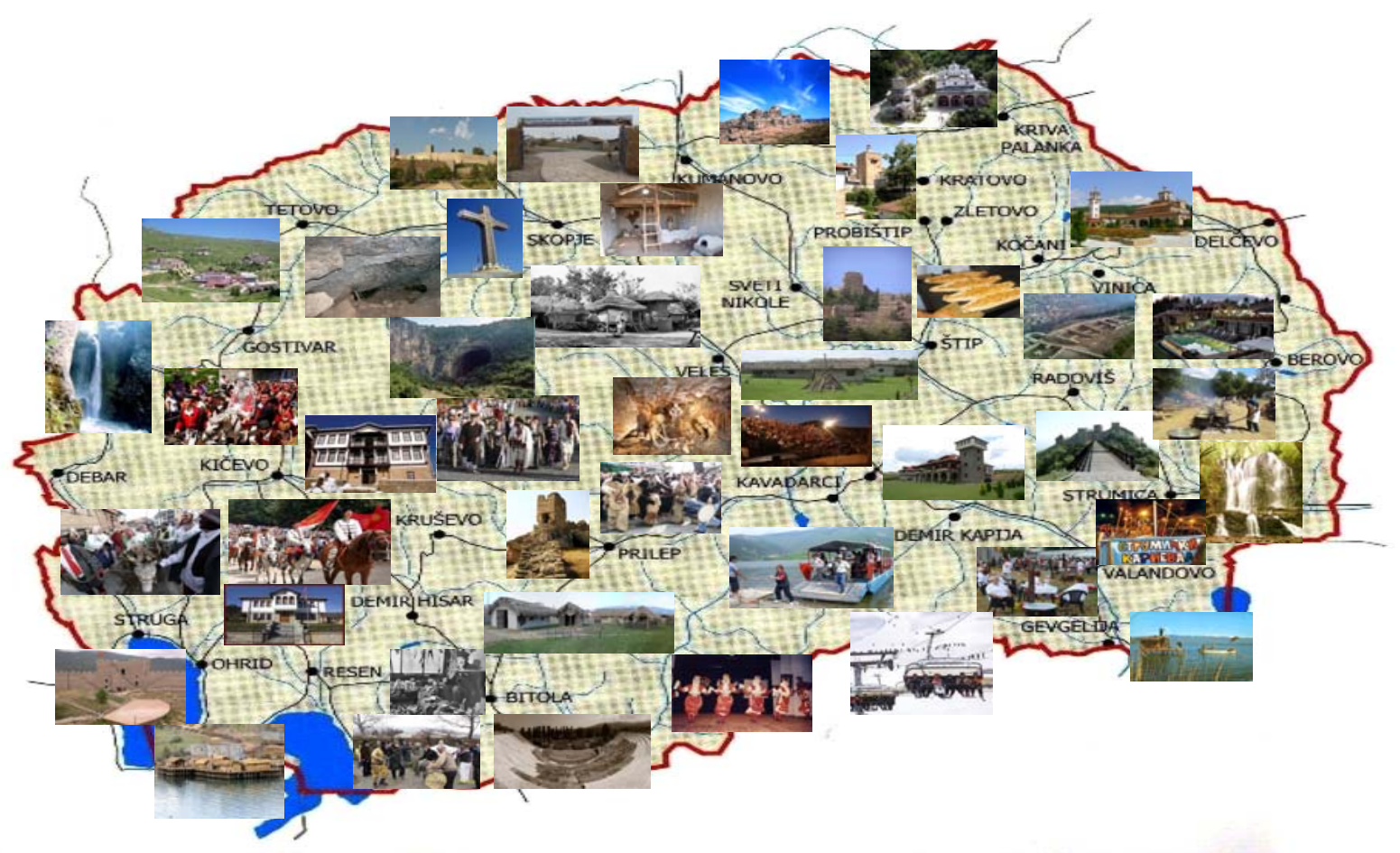

Figure A1. Map—-part of the tourist multimedia events in the Republic of Macedonia. 